\title{
Desain dan Optimasi Antena Pita Lebar Planar Monopole Bentuk Sembarang dengan Algoritma Genetika dan Metode Momen
}

\author{
Joko Suryana $^{*}$ \\ Program Studi Teknik Telekomunikasi, Sekolah Teknik Elektro dan Informatika, Institut Teknologi Bandung \\ Jl.Ganesa 10 Bandung, 40132 Jawa Barat, Indonesia
}

Cara sitasi: J. Suryana, "Desain dan Optimasi Antena Pita Lebar Planar Monopole Bentuk Sembarang dengan Algoritma Genetika dan Metode Momen," Jurnal Teknologi dan Sistem Komputer, vol. 6, no. 2, Apr. 2018. doi: 10.14710/jtsiskom.6.2.2018.84-92, [Online].

\begin{abstract}
This paper presents a new approach in designing an ultra wideband minimum dispersion antenna optimally to avoid the degradation of broadband communications system performance. Design and iterative optimization are applied to an arbitrary shape of planar monopole antenna using a genetic algorithm combined with the moment method, abbreviated as AGMM method, and implemented with Matlab. Two arbitrary shapes of planar monopole antennas have been implemented in compact physical size using AGMM optimization, each having $9.1 \mathrm{GHz}$ and $7.4 \mathrm{GHz}$ bandwidths, the lowest frequency of 1.9 $\mathrm{GHz}$ and $2.7 \mathrm{GHz}$ and fidelity 0.6 and 0.64 for any arbitrary discrete antenna and edge profile antenna. This method can be applied to design any arbitrary shapes of an ultra-wideband antenna with each has wide bandwidth more than $7 \mathrm{GHz}$, the lowest frequency below $3 \mathrm{GHz}$ and a minimum fidelity of 0,55 that is suitable for high-speed communication, such as $5 G$ system.
\end{abstract}

Keywords - ultra wideband antenna; minimum dispersion; genetic algorithm; moment method; optimal antenna

Abstrak - Makalah ini memaparkan pendekatan baru dalam perancangan optimal antena pita lebar dispersi minimum untuk menghindari penurunan kinerja sistem komunikasi kecepatan tinggi. Desain dan optimasi iteratif diterapkan pada antena planar monopole bentuk sembarang menggunakan algoritma genetika yang digabungkan dengan metode momen yang disingkat sebagai metode AGMM. Metode ini diimplementasikan dengan Matlab. Dua buah tipe antena planar monopole pita lebar bentuk sembarang dan ukuran fisik kompak berhasil dirancang dengan AGMM yang masing-masing memiliki lebar pita 9,1 $\mathrm{GHz}$ dan 7,4 GHz, frekuensi terendah 1,9 GHz dan 2,7 GHz serta memiliki fidelity 0,6 dan 0,64 untuk antena diskrit sembarang dan antena profil tepi sembarang. Metode ini dapat diterapkan untuk merancang antena pita lebar bentuk sembarang dengan lebar pita lebih dari $7 \mathrm{GHz}$, frekuensi terendah $<3 \mathrm{GHz}$ dan memiliki

*) Penulis korespondensi (Joko Suryana)

Email: joko.suryana@stei.itb.ac.id fidelity di atas 0,55 yang cocok untuk komunikasi berkecepatan tinggi, misalnya sistem $5 G$.

Kata Kunci - antena pita lebar; dispersi minimum; algoritma genetika; metode momen; antena optimal

\section{Pendahuluan}

Salah satu tantangan dalam sistem komunikasi pita lebar masa depan adalah kebutuhan akan antena yang sesuai untuk mendukung kinerja sistem komunikasi pulsa durasi sangat pendek [1]. Sistem komunikasi kecepatan tinggi (broadband) seperti 5G membutuhkan antena yang dapat bekerja pada pita di bawah $6 \mathrm{GHz}$ maupun di atas $6 \mathrm{GHz}$ untuk transmisi pulsa berdurasi nanodetik dengan distorsi seminimal mungkin. Kebutuhan terhadap antena dengan respons impuls ideal menjadi salah satu pertimbangan utama dalam desain antena.

Suatu antena pita lebar ideal, selain harus memiliki return loss $<-10 \mathrm{~dB}$ pada lebar pita operasi yang disyaratkan, juga harus memiliki karakteristik radiasi medan yang konstan dan fasa linier pada frekuensi operasi tersebut. Dalam domain waktu, kondisi medan konstan dan fasa linier disebut sebagai antena dengan dispersi minimum yang menjamin tidak ada pengurangan kinerja sistem komunikasi pita lebar seperti 5G. Respons impuls antena pengirim dan penerima sangat berpengaruh terhadap kinerja bit error rate (BER) sistem komunikasi pita lebar. Sepasang antena pengirim dan penerima pita lebar dengan dispersi minimum akan memungkinkan korelasi silang yang sempurna antara pulsa terkirim dengan pulsa terima di penerima sehingga simbol dapat dideteksi secara baik.

Riset elektromagnetik mengarah pada upaya untuk menemukan solusi persamaan integral dan diferensial dengan suatu syarat batas, seperti perhitungan impedansi masukan suatu antena, return loss jalur masukan antena dan distribusi arus pada permukaan konduktor antena. Langkah riset ini meliputi formulasi geometri, ukuran dan sifat material yang berkait dengan antena dan lingkungan, pemodelan matematis baik secara eksak maupun dengan metode pendekatan terhadap antena tersebut dan komputasi numerik untuk menemukan solusi bagi perhitungan impedansi masukan desain antena yang diinginkan. 
Perancangan antena dengan suatu optimasi fungsi objektif, seperti penyesuaian impedansi pada suatu rentang pita frekuensi tertentu, merupakan salah satu permasalahan dalam optimasi. Solusi yang dihasilkan dari optimasi tersebut bisa beragam, sehingga dibutuhkan proses pemilihan solusi yang terbaik dari sejumlah alternatif solusi yang ada. Algoritma genetika (AG) telah terbukti dapat digunakan sebagai alat optimasi bagi permasalahan elektromagnetik [2], perancangan antena pita jamak 2,7 GHz, $3 \mathrm{GHz}$ dan 3,3 $\mathrm{GHz}$ [3] dan solusi susunan antena optimum [4]. Algoritma genetika telah digunakan dalam desain dan optimasi antena pita lebar, seperti dalam [5]-[15]. Kebutuhan implementasi antena dengan ukuran kompak tapi mengakomodasi frekuensi rendah juga diperlukan.

Sebagian besar desain dan optimasi antena berbasis algoritma genetika di atas lebih banyak digunakan untuk antena tipe pita terbatas atau tipe pita ganda. Untuk mendapatkan pita yang lebar, algoritma tersebut digabungkan atau digantikan dengan metode lain, seperti particle swarm optimization (PSO) dalam [6]-[9] atau machine learning (ML) dalam [10]. Selain itu, perangkat lunak yang digunakan untuk desain dan simulasi elektromagnetik menggunakan perangkat lunak komersial, seperti HFSS dalam [6], [8], [11] dan CST dalam [5], [9]. Sebagian besar tipe antena yang dipilih adalah antena monopole bukan bentuk sembarang dengan ukuran antena yang tidak kompak dan memiliki respons magnitudo yang terbatas pada pita frekuensi bawah, yaitu rata-rata di frekuensi $3,1 \mathrm{GHz}$.

Penelitian ini mengembangkan antena pita lebar dispersi minimum menggunakan algoritma genetika yang dikombinasikan dengan metode momen. Geometri antena yang digunakan dalam penelitian ini adalah planar monopole bentuk sembarang dengan ukuran fisik yang kompak. Implementasi algoritma genetika dan metode momen menggunakan Matlab, baik simulator analisis antena dengan metode momen maupun simulator algoritma genetika. Optimasi dilakukan untuk mendapatkan antena pita lebar dengan dispersi minimum, yaitu memiliki lebar pita minimum 3,1-10,6 $\mathrm{GHz}$ pada $\mathrm{S}_{11}<-10 \mathrm{~dB}$ dan memiliki respons impuls dengan fidelity tinggi [16].

\section{Metode Penelitian}

Penelitian ini mengembangkan teknik optimasi rancangan antena pita lebar dengan struktur geometrik sembarang menggunakan pendekatan algoritma genetik dan metode momen, yang selanjutnya disebut AGMM. Algoritma genetika diterapkan untuk optimasi rancangan geometri antena planar monopole pita lebar yang dipakai pada pita 3,1-10,6 GHz dengan metode momen. Parameter acuan optimasi rancangan antena dengan AGMM ini mencakup antena dengan pita kerja minimum 3,1-10,6 GHz dengan $\mathrm{S}_{11}<-10 \mathrm{~dB}$ dan dengan profil respon impuls minimum distorsi.

Pendekatan AGMM ini dimulai dengan penggunaan suatu struktur induk dari antena dan melakukan iterasi dengan seleksi alami sehingga didapatkan struktur

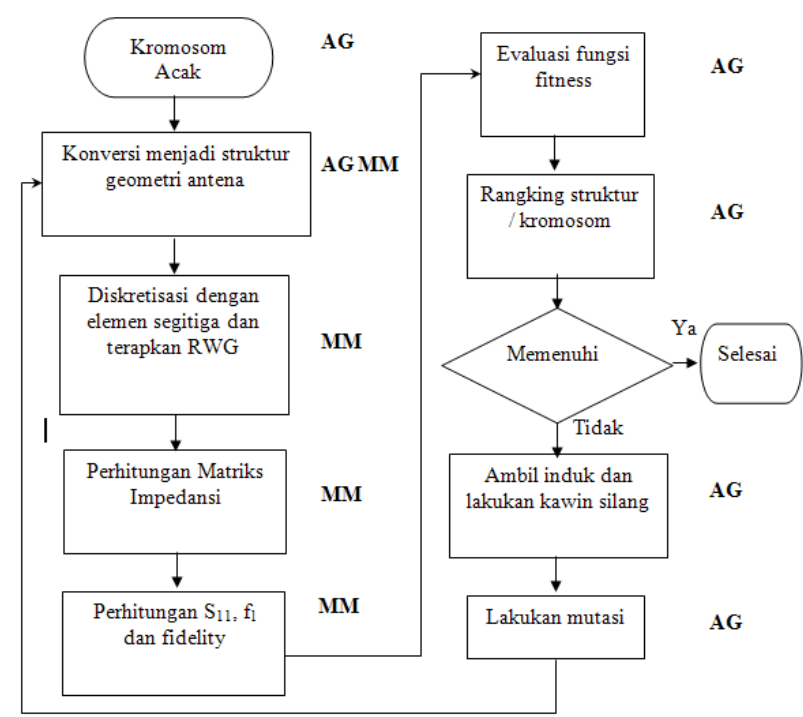

Gambar 1. Diagram alur Algoritma Genetika dan Metode Momen (AGMM) untuk optimasi desain antena

geometrik antena yang optimal sesuai fungsi cost atau fitness yang diinginkan. Diagram alur AGMM ditunjukkan dalam Gambar 1. Algoritma genetika untuk optimasi rancangan ini didahului dengan penentuan populasi awal dari struktur geometrik antena yang dikodekan sebagai kromosom. Setelah itu, kromosom yang merepresentasikan suatu bentuk geometrik antena tersebut dievaluasi dengan metode momen (MM), sehingga didapatkan nilai cost atau fitness untuk kromosom tersebut. Berdasarkan nilai cost / fitness tersebut, kromosom diperbaiki untuk generasi baru mendatang dengan melalui suatu proses reproduksi baik secara silang maupun dengan mutasi. Urutan langkah ini akan diulangi sampai fungsi cost minimum atau fitness tercapai.

Penelitian ini menggunakan pendekatan untuk memaksimalkan fungsi fitness untuk parameter frekuensi terendah, lebar pita yang dihasilkan antena dan profil fidelity domain waktu. Persamaan 1 digunakan sebagai fungsi fitness dari AGMM.

$$
\text { fitness }=0,4\left[\sum_{n=1}^{N} f_{n}\left(S_{11}<-10 d B\right)\right]+0,2\left[N-f_{1}\right]+0,4[\text { fidelity }]
$$

Tujuan optimasi rancangan antena pita lebar adalah dihasilkan struktur antena pita lebar dengan pita frekuensi sangat lebar dengan nilai ideal $1-11 \mathrm{GHz}$ pada $\mathrm{S}_{11}<-10 \mathrm{~dB}$, frekuensi terendah $3,1 \mathrm{GHz}$, dan profil respon impuls antena mempunyai fidelity $>0.5$ atau dengan distorsi oleh grup delay yang masih bisa diterima. Bobot masing-masing parameter yang dioptimasi adalah 40\% untuk lebar pita, 20\% untuk frekuensi terendah yang diinginkan dan $40 \%$ fidelity pulsa kawasan waktu. Nilai fitness minimum yang harus dipenuhi adalah 70, lebar pita minimum minimum 7 $\mathrm{GHz}$, frekuensi terendah $3,1 \mathrm{GHz}$ dan fidelity minimum 0,55 .

Diskretisasi geometrik dilakukan untuk memecah struktur antena ke dalam jumlah elemen-elemen yang lebih kecil. Metode momen ini menggunakan elemen 


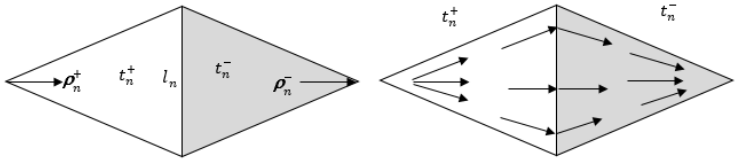

Gambar 2. Sepasang elemen segitiga $t_{n}^{+}$dan $t_{n}^{-}$pada fungsi basis RWG dan vektor fungsi basis RWG

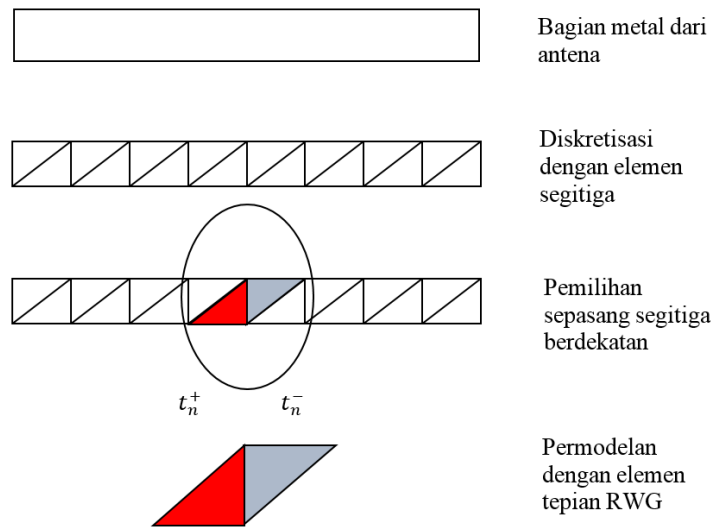

Gambar 3. Tahapan perhitungan numerik metode momen untuk analisis antena

berbentuk segitiga yang lebih akurat daripada elemen kotak [17] dan menggunakan fungsi basis RWG (RaoWilton-Glisson) [18]. Fungsi basis RWG $f_{n}(r)$ dinyatakan dalam Persamaan 2 dan didefinisikan pada sepasang elemen segitiga $t_{n}^{+}$dan $t_{n}^{-}$yang masingmasing memiliki luas sebesar $A_{n}^{+}$dan $A_{n}^{-}$dan tepian bersama $l_{n}$.

$$
\boldsymbol{f}_{n}(\boldsymbol{r})=\left\{\begin{array}{l}
\frac{l_{n}}{2 \boldsymbol{A}_{n}^{+}} \boldsymbol{\rho}_{n}^{+} ; \boldsymbol{r} \text { pada } t_{n}^{+} \\
\frac{l_{n}}{2 \boldsymbol{A}_{n}^{-}} \boldsymbol{\rho}_{n}^{-} ; \boldsymbol{r} \text { pada } t_{n}^{-}
\end{array}\right.
$$

Sepasang segitiga yang digunakan pada fungsi basis RWG ditunjukkan pada Gambar 1. Vektor $\rho_{n}^{+}=r-r_{n}^{+}$ ditarik dari verteks bebas pada segitiga $t_{n}^{+}$ke titik pengamatan $r$. Vektor $\rho_{n}^{-}=r_{n}^{-}-r$ ditarik dari verteks bebas pada segitiga $t_{n}^{-}$ke titik pengamatan $r$. Fungsi basis RWG ini bernilai nol di luar segitiga $t_{n}^{+}$dan $t_{n}^{-}$ serta bersifat linier dan tidak memiliki fluks di perbatasan.

Setiap pasang segitiga berdekatan yang memiliki tepian bersama akan diwakili oleh elemen tepian RWG. Vektor arus listrik permukaan antena merupakan penjumlahan semua kontribusi elemen tepian RWG yang ada dengan sejumlah koefisien yang harganya diselesaikan dengan metode momen. Koefisienkoefisien tersebut diperoleh dari solusi persamaan linier matriks impedansi yang dibentuk oleh persamaanpersamaan momen yang ada. Gambar 3 memperlihatkan tahapan perhitungan numerik untuk analisis antena dengan metode momen dan fungsi basis RWG. Pada penelitian ini, optimasi AGMM digunakan untuk melakukan perbaikan desain antena pita lebar planar

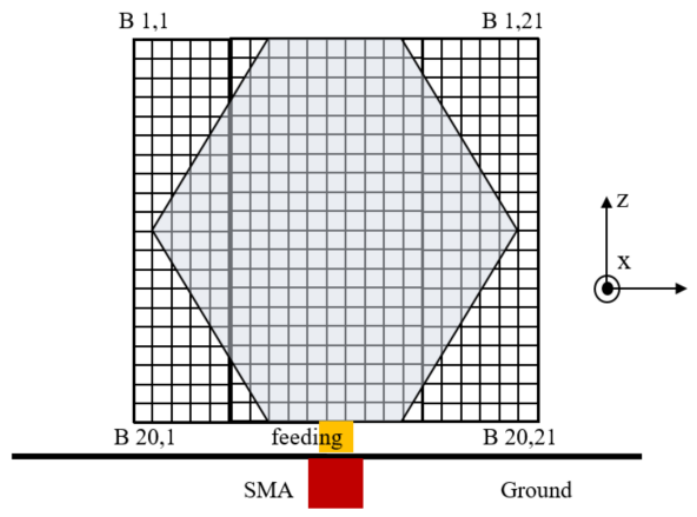

Gambar 4. Model fisik geometrik antena planar monopole geometri sembarang

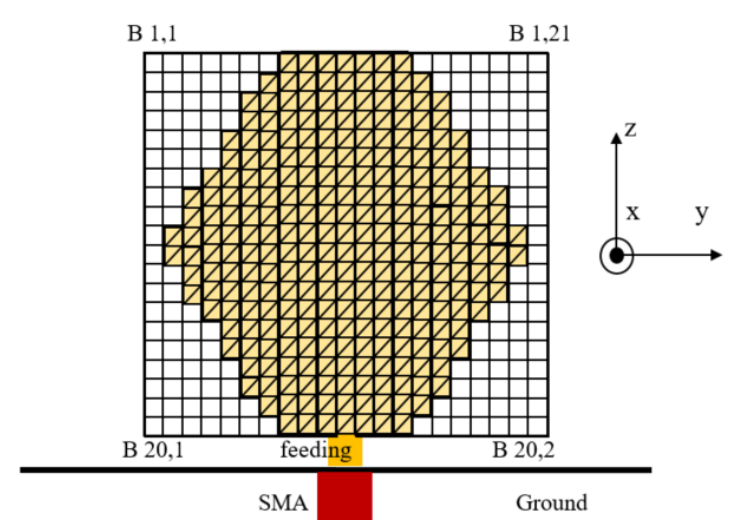

Gambar 5. Model diskretisasi antena dengan elemen segitiga RWG

monopole secara iteratif dengan 2 macam kasus yang berbeda, yaitu optimasi antena dengan bentuk sembarang dan pada monopole Bowtie terbalik dengan tepian sembarang.

\section{A. Optimasi Antena Planar Monopole Diskrit Bentuk Sembarang}

Pada kasus pertama, dirancang antena planar monopole diskrit bentuk sembarang yang mempunyai bagian metal yang dilakukan diskretisasi ke dalam $20 \mathrm{x}$ 21 sub-elemen kotak yang terdiri dari $20 \times 10$ subelemen kiri, $20 \times 1$ sub-elemen tengah dan 20 x 10 subelemen kanan. Model fisik geometrik antena ditunjukkan oleh Gambar 4.

Antena monopole dibuat dari lembar tembaga dengan substrat udara yang dipasang secara normal (arah sumbu z) terhadap ground plane (pada bidang $\mathrm{x}, \mathrm{y}$ ) dengan catuan koaksial di pertengahan dari dasar antena. Karena sifat simetri kiri dan kanan dari antena pita lebar planar monopole, maka hanya diperlukan bentuk antena salah satu sisi, sedangkan sisi lainnya merupakan cermin terhadap sumbu tengah antena. Dari hal tersebut, AG digunakan hanya pada suatu $20 \times 11$ array biner yang dikodekan pada suatu 210 bit kode biner. Array biner $20 \times 11$ ini mewakili bagian metal dari antena dan kode 210 bit tersebut merepresentasikan 


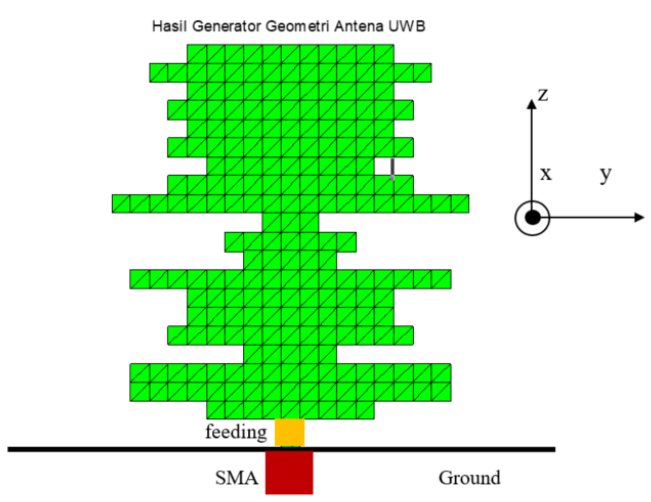

a) Pola 1

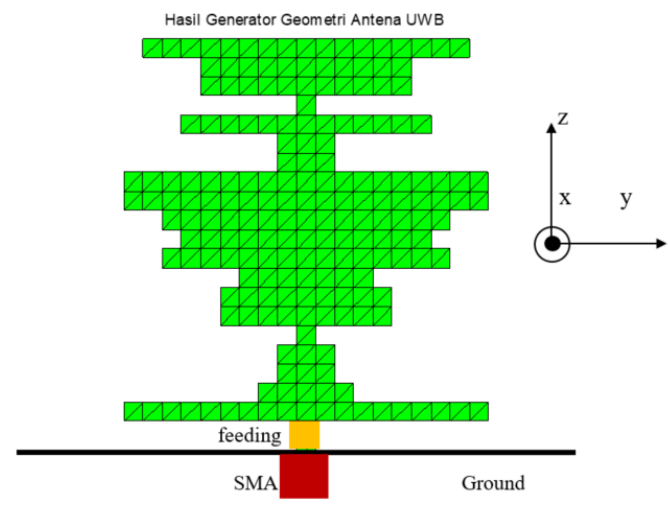

b) Pola 2

Gambar 6. Beberapa pola acak yang dibangkitkan oleh generator pola antena sesuai kromosom yang ada

kromosom. Jika suatu bit berharga ' 1 ', maka area yang diwakili oleh bit tersebut adalah metal, dan jika berharga ' 0 ', maka area tersebut berarti bukan metal. Bentuk struktur geometrik antena yang mungkin adalah sebanyak $2^{210}$ kemungkinan. Elemen kotak tersebut dilakukan diskretisasi menjadi elemen segitiga RWG seperti ditunjukkan oleh Gambar 5.

Beberapa pola acak yang dibangkitkan oleh generator pola antena sesuai kromosom yang ada dalam AG ditunjukkan oleh Gambar 6. Algoritma genetika dimulai dengan membangkitkan secara acak suatu populasi serta berevolusi dengan seleksi, kawin silang dan mutasi. Peluang untuk seleksi didasarkan pada evaluasi kinerja antena dengan fungsi cost/fitness yang diinginkan. Untuk setiap bit yang di-set pada array $20 \mathrm{x}$ 21, suatu kotak 2,5 x 2,5 mm akan disetel sebagai metal berupa konduktor sempurna. Pada simulasi ini, ground plane, posisi konektor SMA dan kondisi batas dibuat tetap untuk semua pola struktur antena yang dievaluasi.

\section{B. Optimasi Antena Planar Monopole dengan Profil Tepian Sembarang}

Pada kasus kedua, bagian metal dari antena pita lebar adalah merupakan antena modifikasi dari Bowtie terbalik dengan profil tepian sembarang. Profil tepian antena planar monopole sangat mempengaruhi lebar pita operasi [19]. Bentuk tapered pada bagian yang dekat dengan ground maupun pada sudut-sudut Bowtie akan memberikan efek peningkatan lebar pita cukup

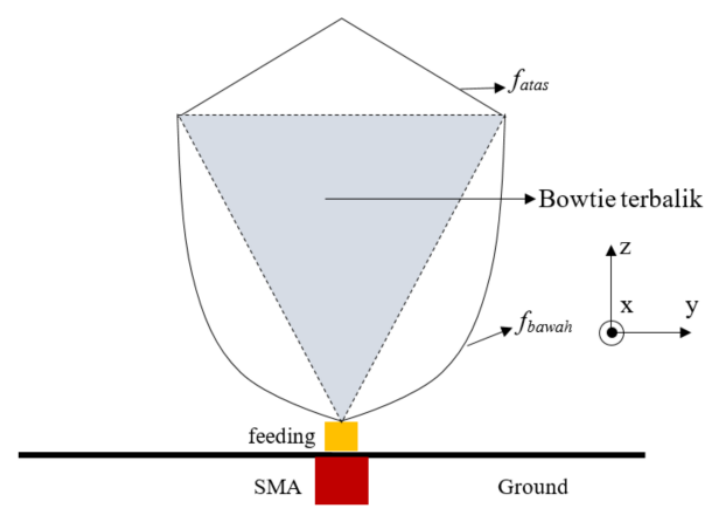

Gambar 7. Model tapered pada tepian antena dekat ground dimodelkan dengan persamaan kuadrat

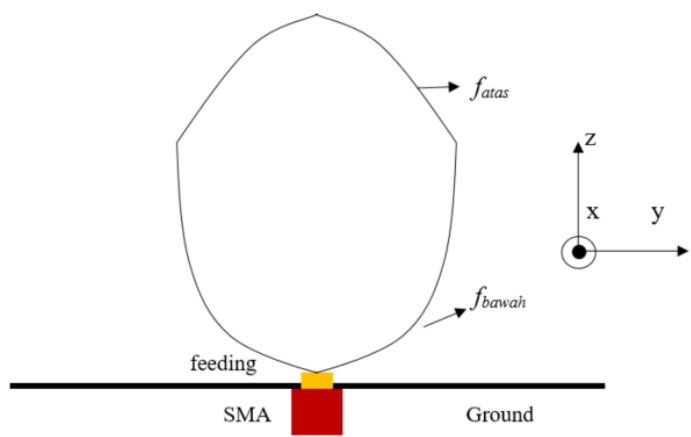

Gambar 8. Model fisik geometrik antena planar monopole tepian sembarang

signifikan sehingga dalam penelitian optimasi antena kasus kedua ini, AG dipakai untuk mencari parameterparameter terbaik dari persamaan tapered pada tepian dekat ground maupun bagian atas dari patch monopole.

Persamaan tapered pada tepian antena dekat ground dimodelkan dengan persamaan kuadrat yang memiliki koefisien $\left[\begin{array}{lll}a_{1} & b_{1} & c_{1}\end{array}\right]$, sedangkan pada tepi atas dimodelkan dengan persamaan kuadrat dengan koefisien $\left[\begin{array}{lll}a_{2} & b_{2} & c_{2}\end{array}\right]$, seperti ditunjukkan dalam Gambar 7. Model ini dinyatakan dalam Persamaan 3 dan Persamaan 4.

$$
\begin{gathered}
f_{\text {bawah }}=a_{1} x^{2}+b_{1} x+c_{1} \\
f_{\text {atas }}=a_{2} x^{2}+b_{2} x+c_{2}
\end{gathered}
$$

Pada kedua persamaan profil tepian Bowtie terbalik terlihat bahwa pada kasus dimana nilai $a_{1}$ atau $a_{2}$ berharga nol, maka kedua persamaan akan merepresentasikan persamaan linier. Jumlah bit yang dipakai untuk mengodekan masing-masing parameter adalah 8 bit, sehingga diperlukan kode biner $3 \times 2 \times 8$ bit untuk merepresentasikan kromosom geometri antena monopole Bowtie terbalik dengan tepian sembarang tertentu.

Dalam penelitian ini, antena monopole dibuat dari lembar tembaga dengan substrat udara yang dipasang secara normal (arah sumbu z) terhadap ground plane (pada bidang $\mathrm{x}, \mathrm{y}$ ) dengan catuan koaksial di pertengahan dari dasar antena. Model fisik geometrik 


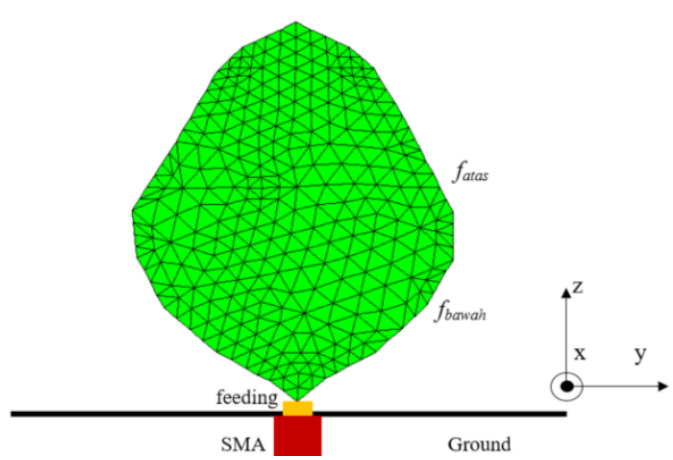

Gambar 9. Model diskretisasi antena dengan elemen segitiga RWG antena planar monopole tepian sembarang

antena ditunjukkan oleh Gambar 8. Model diskretisasi antena dengan elemen segitiga RWG ditunjukkan oleh Gambar 9. Bahan dari konduktor antena ini ditetapkan sebagai metal berupa konduktor sempurna. Pada simulasi ini, ground plane, posisi konektor SMA dan kondisi batas (boundary condition) dibuat tetap untuk semua pola struktur antena yang dievaluasi.

Peluang untuk seleksi dalam algoritma genetika didasarkan pada evaluasi kinerja antena dengan fungsi cost/fitness yang diinginkan. Untuk setiap kromosom 48 bit yang dibangkitkan, suatu struktur antena planar monopole Bowtie terbalik dengan profil tapered pada tepian atas dan bawah radius tertentu dibuat dan dilakukan diskretisasi dengan fungsi basis RWG.

\section{Perhitungan Matriks Impedansi}

Perhitungan impedansi matriks dinyatakan dalam matriks impedansi yang menggambarkan perilaku interaksi elektromagnetik di antara elemen penyusun struktur antena. Bila elemen tepian RWG ke $m$ dan $n$ dianggap sebagai suatu elemen dipole kecil berhingga, maka matriks impedansi $Z_{\mathrm{mn}}$ menggambarkan kontribusi dari dipole $\mathrm{n}$ melalui radiasi medan ke elemen arus listrik pada dipole $m$ dan sebaliknya.

Secara kuantitatif, matriks impedansi $Z_{m n}$ adalah suatu persamaan integral medan listrik sebagaimana dinyatakan dalam Persamaan 5 [16]. Variabel $m$ dan $n$ merupakan dua elemen tepian RWG. Operator (.) merupakan operator perkalian. Variabel $l_{m}$ merupakan panjang tepian dari elemen $m$. Vektor $\rho_{n}^{+}$ditarik dari verteks bebas pada segitiga $t_{n}^{+}$ke titik pengamatan $r$ dan vektor $\rho_{n}^{-}$ditarik dari verteks bebas pada segitiga $t_{n}^{-}$ke titik pengamatan $r$. Vektor $A$ merupakan vektor magnetik potensial yang dinyatakan dalam Persamaan 6 dan $\Phi$ merupakan potensial listrik skalar yang dinyatakan dalam Persamaan 7.

$$
\begin{aligned}
& Z_{m n}=l_{m}\left[j \omega\left(\frac{\boldsymbol{A}_{m n}^{+} \cdot \boldsymbol{\rho}_{m}^{+}}{2}+\frac{\boldsymbol{A}_{m n}^{-} \cdot \boldsymbol{\rho}_{m}^{-}}{2}\right)+\boldsymbol{\Phi}_{m n}^{-}-\boldsymbol{\Phi}_{m n}^{+}\right](5) \\
& \boldsymbol{A}_{m n}^{+}= \\
& \frac{\mu}{4 \pi}\left[\frac{l_{n}}{2 \boldsymbol{A}_{n}^{+}} \int_{t_{n}^{+}} \boldsymbol{\rho}_{n}^{+}\left(\boldsymbol{r}^{\prime}\right) g_{m}^{ \pm}\left(\boldsymbol{r}^{\prime}\right) d S^{\prime}-\frac{l_{n}}{2 \boldsymbol{A}_{n}^{-}} \int_{t_{n}^{-}} \boldsymbol{\rho}_{n}^{-}\left(\boldsymbol{r}^{\prime}\right) g_{m}^{ \pm}\left(\boldsymbol{r}^{\prime}\right) d S^{\prime}\right]
\end{aligned}
$$

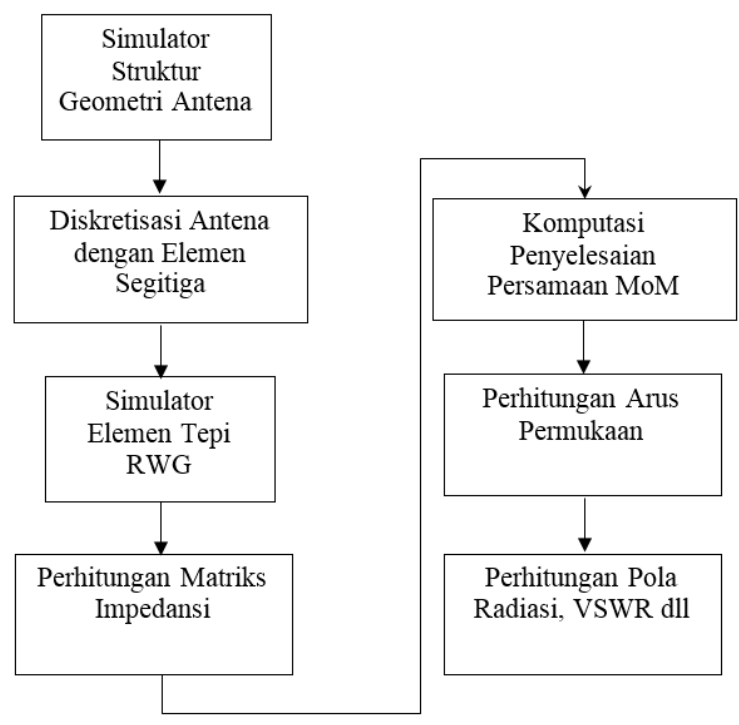

Gambar 10. Alur tahapan implementasi MM/RWG dengan Matlab

$\boldsymbol{\Phi}_{m n}^{ \pm}=\frac{\mu}{j 4 \pi \omega \varepsilon}\left[\frac{l_{n}}{A_{n}^{+}} \int_{t_{n}^{+}} g_{m}^{ \pm}\left(\boldsymbol{r}^{\prime}\right) d S^{\prime}-\frac{l_{n}}{A_{n}^{-}} \int_{t_{n}^{-}} g_{m}^{ \pm}\left(\boldsymbol{r}^{\prime}\right) d S^{\prime}\right]$

dimana :

$$
g_{m}^{ \pm}\left(\boldsymbol{r}^{\prime}\right)=\frac{\exp \left(-j k\left|\boldsymbol{r}_{m}^{ \pm}-\boldsymbol{r}^{\prime}\right|\right)}{\left|\boldsymbol{r}_{m}^{ \pm}-\boldsymbol{r}^{\prime}\right|}
$$

\section{Implementasi MM/RWG dengan MATLAB}

Pada penelitian ini, implementasi komputasi numerik analisis elektromagnetik pada antena dengan metode momen dan RWG dilakukan dengan Matlab yang telah memiliki generator mesh, matriks solver yang efisien, perangkat analisis Fourier serta plot dan operasi 2D dan 3D yang lengkap. Tahapan keseluruhan implementasi simulasi analisis antena pita lebar menggunakan Matlab mengikuti diagram alur sebagaimana ditunjukkan dalam Gambar 10.

Matriks mesh dalam rancangan struktur geometri antena diperoleh dengan menggunakan mesh generator dari toolbox PDE (partial differential equation) [20]. Matriks mesh ini mewakili struktur geometri antena dan digunakan dalam identifikasi pasangan segitiga yang berdekatan dan menentukan tepi yang dipakai bersama oleh pasangan segitiga tersebut. Tahapan ini akan menghasilkan elemen tepi RWG sehingga siap dipakai untuk perhitungan matriks impedansi.

Setelah diperoleh dua rancangan antena pita lebar dengan metode optimasi AGMM tersebut, pengukuran antena dilakukan menggunakan perangkat Vector Network Analyzer 0-13,5 GHz di laboratorium Telekomunikasi Radio dan Gelombang Mikro ITB (LTRGM). Pola radiasi antena hasil optimasi AGMM dilakukan dengan menggunakan perangkat lunak komersial Flomerics MICROSTRIPES.

\section{Hasil dan Pembahasan}

Penelitian ini menghasilkan dua rancangan antena pita lebar dengan metode optimasi AGMM, yaitu antena planar monopole diskrit bentuk sembarang (antena I) 


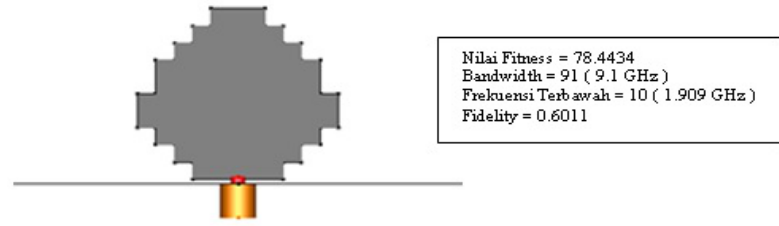

Gambar 11. Hasil optimasi antena diskrit bentuk sembarang (antena I)

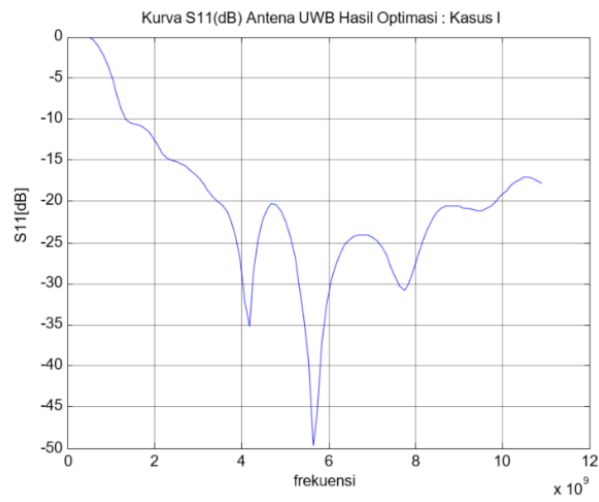

Gambar 12. Kurva $S_{11}$ antena pita lebar hasil optimasi dengan AGMM untuk kasus I

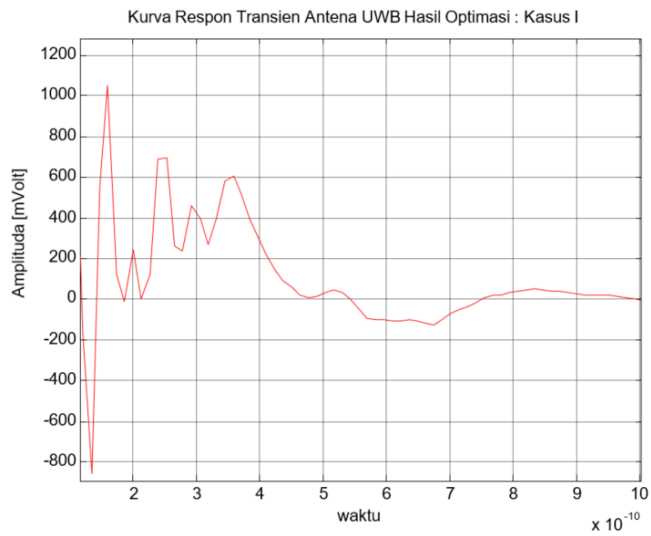

Gambar 13. Respons impuls antena pita lebar hasil optimasi dengan AGMM untuk kasus I

dan antena monopole Bowtie terbalik dengan tepian sembarang (antena II).

\section{A. Antena Hasil Desain dan Optimasi AGMM}

Optimasi dengan algoritma AGMM menghasilkan banyak antena pita lebar cincin yang memenuhi fungsi fitness yang telah ditentukan dalam penelitian. Dalam penelitian ini hanya ditunjukkan dua contoh antena planar monopole bentuk sembarang hasil optimasi, baik kasus I maupun kasus II. Karakterisasi antena meliputi kurva $\mathrm{S}_{11}$ dan respons impuls.

Hasil desain antena planar monopole bentuk sembarang kasus I ditunjukkan dalam Gambar 11. Kurva $S_{11}$ dan respons impuls antena pita lebar hasil optimasi dengan AGMM ditunjukkan dalam Gambar 12 dan Gambar 13. Hasil desain antena planar monopole tapered atas dan bawah profil sembarang untuk kasus II ditunjukkan dalam Gambar 14. Kurva $\mathrm{S}_{11}$ dan respons

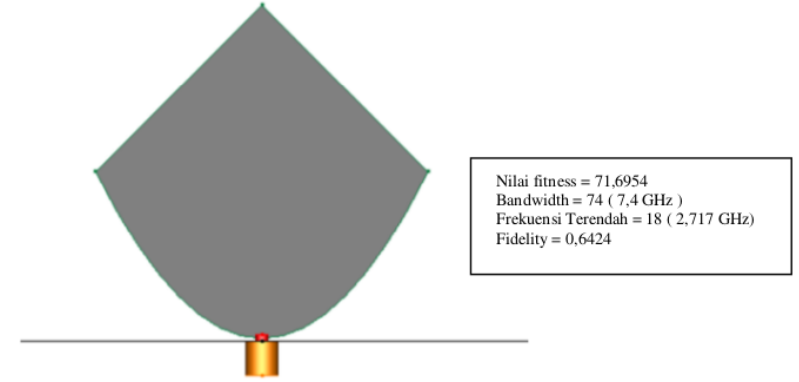

Gambar 14. Hasil optimasi antena tepian sembarang (antena II)

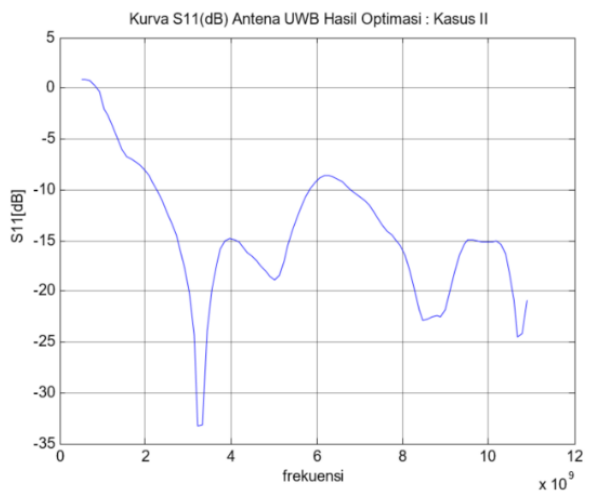

Gambar 15. Kurva $S_{11}$ antena pita lebar hasil optimasi dengan AGMM untuk kasus II

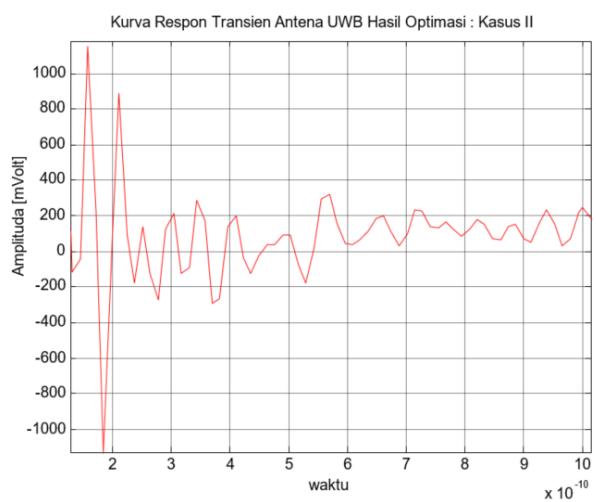

Gambar 16. Respons impuls antena pita lebar hasil optimasi dengan AGMM untuk kasus II

impuls antena pita lebar hasil optimasi dengan AGMM ditunjukkan dalam Gambar 15 dan Gambar 16.

Antena I memiliki nilai fitness mencapai 78,4, sedangkan antena II memiliki fitness mencapat 71,7. Dari hal tersebut, persyaratan optimasi telah terpenuhi frekuensi terendah, lebar pita yang dihasilkan antena dan profil fidelity domain waktu tercapai dengan baik. Antena I memiliki frekuensi terendah 1,9 GHz, lebar pita $9,1 \mathrm{GHz}$ dan fidelity 0,6 sehingga antena ini bisa digunakan untuk komunikasi pita lebar dengan distorsi minimal. Antena II mempunyai frekuensi terendah 2,7 $\mathrm{GHz}$, lebar pita 7,4 GHz dan fidelity 0,64 sehingga antena ini juga bisa digunakan untuk komunikasi pita lebar dengan distorsi minimal. 

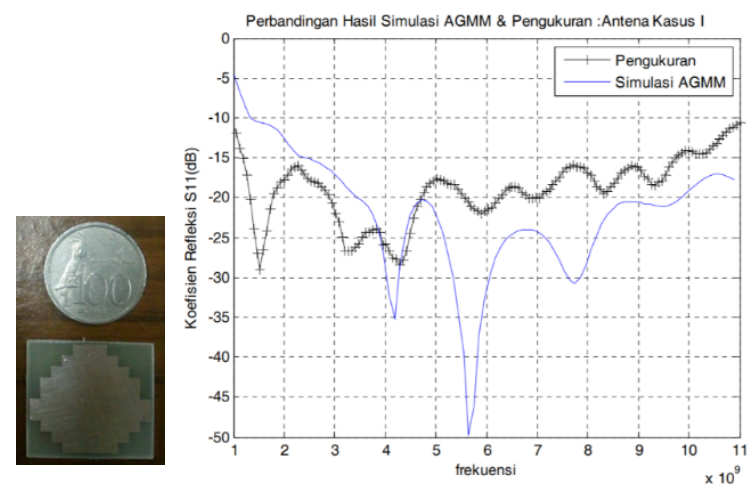

Gambar 17. a) Foto bentuk fisik antena I dan b) hasil pengukurannya vs simulasi return loss
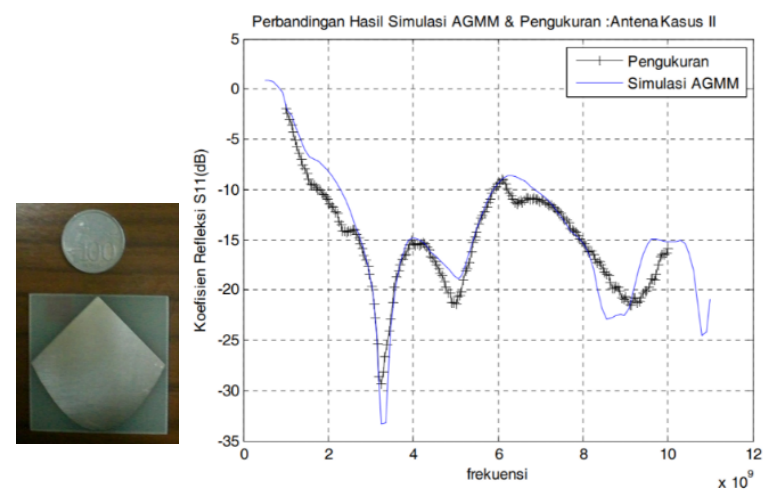

Gambar 18. a) Foto bentuk fisik antena II dan b) hasil pengukurannya vs simulasi return loss

\section{B. Hasil Implementasi dan Pengukuran Antena}

Hasil desain dan optimasi antena diharapkan memenuhi spesifikasi teknis yang diinginkan yaitu lebar pita minimum $7 \mathrm{GHz}$, frekuensi terendah $<3,1$ $\mathrm{GHz}$ dan memiliki fidelity minimum 0,55 . Penelitian ini mengimplementasikan antena planar monopole bentuk sembarang menggunakan material PCB untuk membuat ground beserta bagian monopolenya.

Foto fisik antena tipe I setelah diimplementasikan di atas material PCB ditunjukkan dalam 17a. Tingkat akurasi AGMM yang diimplementasikan dengan perangkat lunak Matlab dan hasil pengukuran parameter return loss $\mathrm{S}_{11}$ menggunakan VNA 0-13.5 GHz ditunjukkan dalam Gambar 17b. Foto fisik antena tipe II ditunjukkan dalam 18a. Tingkat akurasi AGMM yang diimplementasikan dengan perangkat lunak Matlab dan hasil pengukuran parameter return loss $\mathrm{S}_{11}$ menggunakan VNA 0-13.5 GHz ditunjukkan dalam Gambar 18b.

Parameter $\mathrm{S}_{11}$ mencerminkan pantulan akibat ketidaksesuaian antara impedansi masukan antena terhadap saluran transmisi $50 \mathrm{ohm}$. Dari Gambar $17 \mathrm{~b}$ dan Gambar 18b terlihat bahwa hasil optimasi AGMM atas model antena memiliki akurasi yang baik dibandingkan dengan hasil pengukuran prototip dengan menggunakan peralatan ukur VNA 0-13,5 GHz. AGMM dapat digunakan dalam perancangan antena pita lebar dispersi minimum sehingga dapat digunakan untuk
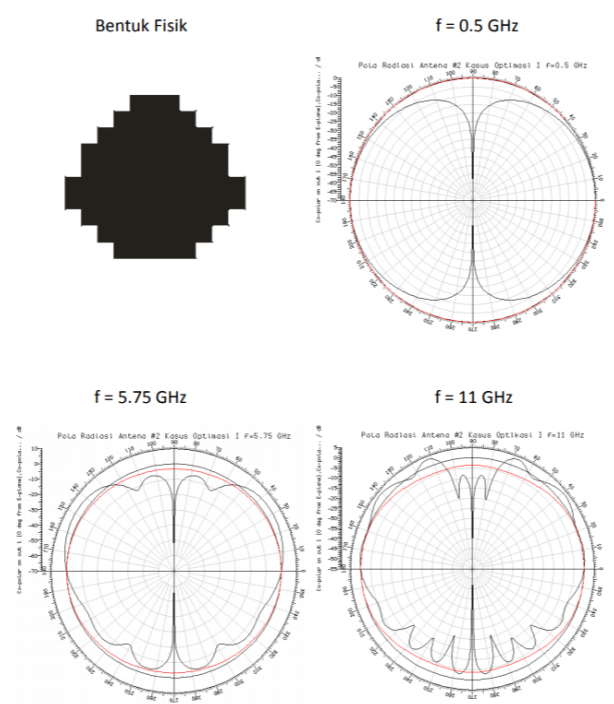

Gambar 19. Simulasi pola radiasi antena I
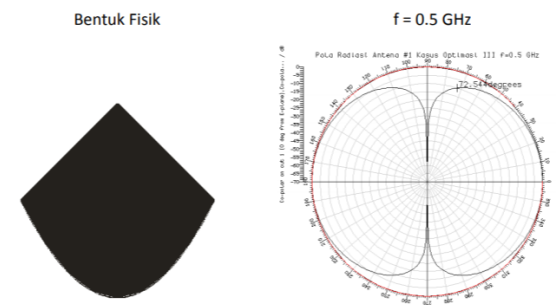

$f=5.75 \mathrm{GHz}$

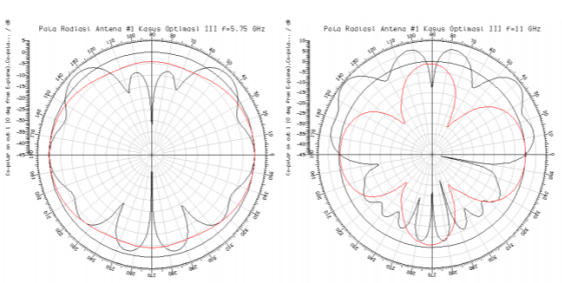

Gambar 20. Simulasi pola radiasi antena II

menghindari penurunan kinerja sistem komunikasi kecepatan tinggi seperti sistem $5 \mathrm{G}$.

\section{Pola Radiasi Antena Planar Monopole Bentuk Sembarang}

Simulasi pola radiasi antena hasil optimasi AGMM disajikan berturut-turut untuk struktur antena kasus 1 dan antena kasus 2 untuk $\mathrm{f}=0,5 \mathrm{GHz}, \mathrm{f}=5,75 \mathrm{GHz}$ dan $\mathrm{f}=11 \mathrm{GHz}$ menggunakan software komersial MICROSTRIPES. Gambar 19 dan Gambar 20 menunjukkan pola radiasi antena I dan II pada beberapa frekuensi kerja, yaitu masing-masing di $0,5 \mathrm{GHz}, 5,75$ $\mathrm{GHz}$ dan $11 \mathrm{GHz}$. Terlihat dari hasil simulasi pola radiasi antena pada beberapa frekuensi tersebut bahwa planar monopole bentuk sembarang dan planar monopole tepian sembarang memiliki pola radiasi yang khas dari suatu antena monopole baik pada frekuensi rendah yaitu $0,5 \mathrm{GHz}$, frekuensi tengah di $5,75 \mathrm{GHz}$ serta di frekuensi tinggi $11 \mathrm{GHz}$ dan pola radiasinya stabil. 
Desain dan optimasi menggunakan AGMM sesuai untuk penerapan komunikasi pita lebar dengan dispersi minimum seperti dalam [16]. Penelitian ini menghasilkan metode baru dalam optimasi antena monopole pita lebar menggunakan algoritma genetika dan metode momen, selain dengan PSO [6]-[9] dan ML [10]. Algoritma genetika dalam metode AGMM digunakan untuk mendapatkan antena pita lebar dengan pendekatan fungsi objektif gabungan antena domain frekuensi dan domain waktu, yaitu $40 \%$ parameter $\mathrm{S}_{11}$, $20 \%$ frekuensi terendah dan dan $40 \%$ respons impuls yang dinyatakan dalam parameter fidelity.

Dibandingkan dengan [5], [6], [8], [9] dan [11] yang menggunakan perangkat lunak komersial khusus untuk desain dan simulasi antena, metode AGMM dapat diimplementasikan dengan menggunakan perangkat lunak Matlab. Metode ini juga memungkinkan bentuk case antena monopole berupa bentuk sembarang, di antaranya monopole diskrit sembarang dan tepi sembarang yang dipilih dalam penelitian ini.

Hasil pengukuran parameter $S_{11}$ untuk kedua antena tersebut memperlihatkan bahwa metode AGMM telah secara efektif menghasilkan rancangan antena pita lebar dengan spesifikasi yang hampir sama dengan hasil pengukuran di laboratorium. Hasil pengukuran menunjukkan bahwa implementasi antena dengan AGMM memiliki lebar pita minimal $7 \mathrm{GHz}$ untuk $\mathrm{S}_{11}<$ $-10 \mathrm{~dB}$ dan frekuensi terendah mencapai $<3 \mathrm{GHz}$ pada fidelity di atas 55\% sehingga dapat digunakan untuk sistem 5G dengan pita jamak, seperti dalam [2]-[4].

Metode AGMM ini mengakomodasi pita bawah dalam fungsi objektif dengan bobot $20 \%$ dan dapat menghasilkan rancangan antena dengan pita lebar dan frekuensi minimum yang lebih rendah sampai $1 \mathrm{GHz}$ daripada yang dihasilkan dalam penelitian lain yang memiliki respons magnitudo terbatas pada pita frekuensi bawah rata-rata di 3,1 GHz, seperti dalam [5], [7], [9], [15], namun tetap mempertahankan ukuran fisik yang kompak (Gambar 17 dan 18). Hasil desain AGMM berupa antena I mempunyai lebar pita dan frekuensi terendah yang lebih baik yaitu $9,1 \mathrm{GHz}$ dan $1,9 \mathrm{GHz}$ daripada antena II dengan lebar pita 7,4 GHz dan 2,7 GHz. Namun, hasil antena II mempunyai fidelity yang lebih baik sebesar 0,64 daripada antena I sebesar 0,6 sehingga sedikit lebih baik dalam minimalisasi distorsi sinyal pita dasar.

\section{KESIMPULAN}

Teknik optimasi AGMM dapat menghasilkan prototip antena pita lebar berupa planar monopole diskrit bentuk sembarang dan planar monopole dengan profil tepian sembarang yang memiliki lebar pita lebih dari $7 \mathrm{GHz}$, frekuensi terendah kurang dari $3 \mathrm{GHz}$ dan memiliki fidelity di atas 0,55. Teknik AGMM yang menggabungkan fungsi objektif gabungan antena domain frekuensi dan domain waktu dapat diimplementasikan dengan perangkat lunak Matlab.

\section{Daftar Pustaka}

[1] J. Suryana, "The Rainfall Intensity Effects on 1$13 \mathrm{GHz}$ UWB-Based 5G System for Outdoor Applications", Wireless Communications and Mobile Computing, volume 2017, pp. 1-13, 2017.

[2] R. L. Haupt and D. H. Werner, Genetic Algorithms in Electromagnetics. John Wiley \& Sons, 2007.

[3] J. M. Johnson and Y. Rahmat-Samii, "Genetic Algorithm and Method of Moments (GA/MoM) for the Design of Integrated Antennas," IEEE Transactions on Antennas and Propagation, vol. 47, no. 10, pp. 1606-1614, Oct. 1999.

[4] D. W. Boeringer, D. W. Mchuga, and D. H. Werner, "Synthesis of Phased Array Amplitude Weights for Stationary Sidelobe Envelopes using Genetic Algorithms," in IEEE Antennas and Propagation Society International Symposium, Boston, 8-13 July 2001, pp. 684-687.

[5] A. B. Teirab, J. A. Jervase, and S. S. Mneina, "Design of UWB Monopole Antenna using Genetic Algorithms," in 2013 7th IEEE GCC Conference and Exhibition (GCC), Doha, 17-20 Nov. 2013, pp. 89-92.

[6] Y. L. Li, W. Shao, L. You, and B. Z. Wang, "An Improved PSO Algorithm and Its Application to UWB Antenna Design," IEEE Antennas and Wireless Propagation Letters, vol. 12, pp. 12361239, 2013.

[7] A. Deb, J. S. Roy, and B. Gupta, "Performance Comparison of Differential Evolution, Particle Swarm Optimization and Genetic Algorithm in the Design of Circularly Polarized Microstrip Antennas," IEEE Transactions on Antennas and Propagation, vol. 62, no. 8, pp. 3920-3928, Aug. 2014.

[8] Y. Wu, X. Wang, Y. Wang, S. Rashid, Y. Ding, and Y. Zhang, "The Design and Optimization of Ultra Wideband Antenna Based on Particle Swarm Algorithm," in IEEE International Conference on Computational Electromagnetics (ICCEM 2016), Guangzhou, 23 - 25 February 2016, pp. 205-207.

[9] H. J. Mohammed, A. S. Abdullah, R. S. Ali, Y. I. Abdulraheem, and R. A. Abd-Alhameed, "Performance Comparison of Particle Swarm Optimization, And Genetic Algorithm in The Design Of UWB Antenna," Journal of Telecommunications, vol. 27, no. 2, pp. 22-26, 2014.

[10] S. R. Martins, H. W. C. Lins, and C. R. M. Silva, "A Self-organizing Genetic Algorithm for UWB Microstrip Antenna Optimization Using a Machine Learning Technique," in International Conference on Intelligent Data Engineering and Automated Learning, Berlin, 2012, pp 642-649.

[11] C. R. M. Silva, H. W. C. Lins, S. R. Martins, E. E. F. Barreto, and A. G. D'Assunção, "A Multiobjective Optimization of a UWB Antenna using a Self Organizing Genetic Algorithm," 
Microwave and Optical Technology Letters, vol. 54, no. 8, pp. 1824-1828, Aug. 2012.

[12] J. Jayasinge, J. Anguera, and D. Uduwala, "Genetic Algorithm Optimization of a HighDirectivity Microstrip Patch Antenna Having a Rectangular Profile," Radioengineering, vol. 22, no. 3, Sept. 2013.

[13] M. H. Miry, G. A. Al-Suhail, F. Abdussalam, M. B. Child, and R. A. Abd-Alhameed, "Design of a Small Ultra Wideband Antenna using a Genetic Algorithm Approach", in Internet Technologies and Applications (ITA), 2015, pp. 461-465.

[14] M. T. Asghar, M. F. Shafique, I. Usman, N. Gogosh, and M. A. Khan, "Design and Optimization of an UWB Antenna with $5.8 \mathrm{GHz}$ Band Suppression Using Genetic Algorithm," Journal of Basic and Applied, vol. 3, no. 7, pp. 701-707, 2013.

[15] K. Fertas, H. Kimouche, M. Challal, F. Ghanem, F. Fertas, and R. Aksas, "Development of a Novel UWB Planar Antenna using a Genetic Algorithm," in 2017 5th International Conference on Electrical
Engineering-Boumerdes (ICEE-B), Boumerdes, 29 Oct. 2017, pp. 1-4.

[16] G. Quintero, J. F. Zürcher, and A. K. Skrivervik, "System Fidelity Factor: A New Method for Comparing UWB Antennas," IEEE Transactions on Antennas and Propagation, vol. 59, no. 7, pp. 2502-2512, 2011.

[17] Davidson, Computational Electromagnetics for $R F$ and Microwave Engineering. Cambridge University Press, July 2014.

[18] S. M. Rao, D. R. Wilton, and A. W. Glisson, "Electromagnetic Scattering by Surfaces of Arbitrary Shape," IEEE Transactons on Antennas and Propagation, vol. 30, no. 3, pp. 409-418, May 1982.

[19] B. Kaur and L. S. Solanski, "A Brief Review on Bowtie Antenna," in Proc. National Conference on Communication \& Networking (NCCN-12), 3-4 February 2012.

[20] Mathworks Inc, Partial Differential Equation Toolbox For Use with MATLAB. February 1996. 